\title{
LAYANAN BIMBINGAN DAN KONSELING BERBASIS CYBER UNTUK MENINGKATKAN KETERAMPILAN BERPIKIR KRITIS SISWA
}

\author{
I Made Sonny Gunawan ${ }^{1^{*}}$, Siti Zahra Bulantika ${ }^{2}$, Permata Sari ${ }^{2}$ \\ ${ }^{1}$ Universitas Pendidikan Mandalika, Indonesia \\ ${ }^{2}$ UIN Raden Intan Lampung, Indonesia
}

\begin{tabular}{ll}
\hline \hline & Abstract \\
\hline $\begin{array}{l}\text { Keywords: } \\
\text { guidance }\end{array}$ & $\begin{array}{l}\text { The government's decision to move the learning process from school to home made } \\
\text { and }\end{array}$ \\
$\begin{array}{l}\text { many teachers and school counselors suffer from confusion. Judging from the } \\
\text { learning process carried out in school with the assistance of the teacher, there are still } \\
\text { services } ; \\
\text { cyber } \\
\text { critical } \\
\text { thinking }\end{array}$ & $\begin{array}{l}\text { atmosphere who have to study alone at home without mentoring that only relies on } \\
\text { independent tasks. This problem illustrates that the teacher's role is very central in } \\
\text { helping students to be able to develop their critical thinking skills in solving a } \\
\text { problem. Especially in this case the guidance and counseling teacher or school } \\
\text { counselor has an important role to be able to facilitate students in developing their } \\
\text { potential according to the current pandemic situation by utilizing technological } \\
\text { advances. }\end{array}$
\end{tabular}

Keywords: guidance and counseling services, cyber, critical thinking

\section{Abstrak:}

\section{Kata Kunci:}

layanan

bimbingan dan

konseling ;

cyber;

berpikir kritis.
Keputusan pemerintah yang memindahkan proses pembelajaraan dari sekolah menjadi di rumah membuat banyak guru dan konselor sekolah mengalami kelimpungan. Meninjau dari proses pembelajaran yang dilakukan di sekolah dengan adanya pendampingan oleh guru, masih ditemui banyaknya siswa yang pasif dan tidak mampu untuk berpikir kritis apa lagi dalam suasana saat ini yang harus belajar sendiri dirumah tanpa pendampingan yang hanya bertumpu pada tugas-tugas mandiri. Permasalahan ini menggambarkan bahwa peran guru sangat sentral di dalam membantu siswa untuk mampu mengembangkan kemampuan berpikir kritisnya di dalam menyelesaikan suatu permasalahan. Khususnya untuk guru bimbingan konseling atau konselor sekolah memiliki peran penting untuk dapat memfasilitasi siswa dalam mengembangkan potensi yang dimiliki sesuai keadaan pandemic saat ini adalah dengan memanfaatkan kemajuan teknologi.

Kata kunci: layanan bimbingan dan konseling, cyber, berpikir kritis 


\section{PENDAHULUAN}

Saat ini dunia pendidikan memerlukan ide-ide kreatif dan inovatif untuk menunjang proses pembelajaran bagi siswa yang dilakukan melalui rumah akibat pandemik Covid 19 atau Corona Virus diseases-19. Keputusan pemerintah yang memindahkan proses pembelajaraan dari sekolah menjadi di rumah membuat banyak guru dan konselor sekolah mengalami kelimpungan. Hal ini juga dipicu oleh belum adanya kesiapan dari para guru dan konselor sekolah untuk melakukan proses pendidikan secara daring. Selain itu, peralihan pembelajaran ini secara tidak langsung dapat menyebabkan siswa mengalami kecemasan yang tinggi karena memaksakan mereka untuk mampu menyelesaikan tugas-tugas yang semakin banyak tanpa adanya pendampingan secara khusus dari guru yang dapat membantu mereka untuk berfikir kritis di dalam menyelesaikan tugas-tugas tersebut. Lebih lanjut, masalah tersebut perlu mendapatkan perhatian khusus dari para pemangku kebijakan agar tidak berdampak negatif pada perkembangan kepribadian siswa.

Adapun berdasarkan hasil penelitian yang dilakukan menunjukkan bahwa kemampuan siswa dalam berfikir kritis untuk memecahkan permasalahan masih pada kategori tidak memuaskan (Chotimah et al., 2019). Lebih lanjut, permasalahan ini terjadi karena siswa di sekolah terbiasa pasif dan tidak terbiasa untuk berpikir kritis dalam pemecahan masalah. Meninjau dari proses pembelajaran yang dilakukan di sekolah dengan adanya pendampingan oleh guru, masih ditemui banyaknya siswa yang pasif dan tidak mampu untuk berpikir kritis apa lagi dalam suasana saat ini yang harus belajar sendiri dirumah tanpa pendampingan yang hanya bertumpu pada tugas-tugas mandiri.

Permasalahan ini menggambarkan bahwa peran guru sangat sentral untuk membantu siswa agar mampu mengembangkan kemampuan berpikir kritisnya di dalam menyelesaikan suatu permasalahan. Khususnya untuk guru bimbingan konseling dan konselor sekolah mempunya peran penting agar dapat memfasilitasi siswa mengembangkan potensi yang dimiliki dari kondisi yang dirasa kurang menuju efektif dan menjadi probadi yang utuh, berkarakter dan mandiri (ABKIN, 2008).

Adapun upaya konselor sekolah atau guru bimbingan dan konseling di dalam membantu mengatasi permasalahan siswa untuk mencapai perkembangan pribadi yang optimal di situasi pandemik saat ini adalah dengan memanfaatkan kemajuan teknologi. Menurut (Gibson et al., 2010) guru bimbingan dan konseling atau konselor sekolah harus kompeten di dalam menggunakan komputer atau smart phone yang dapat berimplikasi besar bagi praktiknya. Senada dengan pernyataan tersebut Triyono \& Febriani (2018) 
mengungkapkan jika penggunaan teknologi dalam pelayanan bimbingan dan konseling dapat dimanfaatkan sebagai alat bantu di dalam mengembangkan potensi siswa.

Lebih lanjut, alat-alat atau media yang dapat digunakan oleh konselor sekolah di dalam membantu siswa menyelesaikan permasalahan yang dihadapi saat ini adalah dengan memanfaatkan teknologi berupa smart phone dan komputer yang dapat terkoneksi dengan jaringan internet. Adapun media informasi tersebut dapat digunakan oleh konselor sekolah sebagai alat alternatif di dalam memberikan pelayanan terhadap siswa. Melihat pentingnya penggunaan teknologi sebagai penunjang kinerja maka diharapkan konselor sekolah untuk melek teknologi dan terlatih dalam penerapannaya. Salah satu bentuk aplikasi yang saat ini dapat dikembangkan dan dimanfaatkan oleh konselor sekolah adalah e-konseling (Prasetyo \& Djuniadi 2015).

Dalam penerapannya e-konseling merupakan kata lain dari pemberian layanan bimbingan dan konseling berbasis cyber yang menguntungkan bagi kedua belah pihak. Melihat kemungkinan tersebut maka pada akhirnya konselor professional akan di tuntut untuk dapat menyediakan layanan konseling secara online dengan memanfaatkan berbagai macam teknologi. Selanjutnya, penggunaan teknologi berbasis cyber di harapkan dapat membantu mempermudah pekerjaan konselor dalam memberikan pelayanan terbaik bagi siswa di sekolah maupun di luar lingkungan sekolah (Matthews, dkk 2008).

Lebih lanjut, Bhatt (2013) menjelaskan jika penggunaan teknologi dalam dunia pendidikan harus dapat dipahami sebagai bentuk implementasi dari kemajuan ilmu pengetahuan untuk memajukan pendidikan itu sendiri. Dalam hal ini penggunaan teknologi yang khususnya dalam bidang bimbingan dan konseling dapat dimanfaatkan untuk memberikan layanan yang sesuai dengan kebutuhan siswa dimanapun mereka berada tanpa adanya batasan waktu. Pernyataan tersebut diperkuat oleh Cabaniss (2003) yang mengungkapkan jika teknologi informasi harus dimiliki oleh seorang konselor untuk menunjang layanan terapi dan konsultasinya bagi siswa.

\section{METODE}

Penelitian ini merupakan penelitian yang menggunakan pendekatan kualitatif dengan menerapkan metode penelitian library research. Pengumpulan data pada penelitian ini menggunakan data sekunder berupa buku-buku, jurnal hasil penelitian, berita di media masa dan dokumen-dokumen tertulis lainnya mengenai cyber counselling dan berpikir kritis. Teknik analisis yang digunakan adalah content analysis, teknik ini digunakan untuk 
menjawab atau mendeskripsikan pertanyaan penelitian. Hasil content analysis ini kemudian digunakan sebagai bahan untuk menjawab pertanyaan penelitian pada tahap selanjutnya bersama dengan data lain yang diperoleh.

\section{HASIL}

Adapun hasil penelitian ini menunjukkan bahwa siswa yang mampu berpikir kritis memiliki indikator dapat membuat kesimpulan dan mengarah pada pengambilan keputusan yang lebih baik dengan penuh keyakinan dan memiliki nilai-nilai untuk kekuatan mentalnya. Hal ini ditandai dengan memiliki kompetensi diri seperti nilai kemandirian, keingintahuan, kerendahan hati, dan penalaran yang baik. Melalui keterampilan berpikir kritis, konsep pelajaran yang didapat tidak hanya sekedar dihafalkan saja, tetapi menjadikan proses belajar siswa lebih bermakna. Selain itu, pengambilan keputusan yang dilakukan siswa akan didasarkan pada pertimbangan yang logis.

\section{PEMBAHASAN}

Berpikir kritis merupakan kemampuan ataupun strategi kognitif untuk meningkatkan peluang sukses di dalam mengatasi masalah yang dihadapi (Dahlia, Ibrahim, \& Mahanal, 2018). Lebih lanjut, berpikir kritis dikatakan sebagai salah satu keterampilan utama yang mempersiapkan siswa untuk mampu menghadapi perubahan yang cepat dan berkesinambungan di era globalisasi saat ini (Tiruneh, Gu, De Cock, \& Elen, 2018). Peran berpikir kritis dalam pembelajaran dipengaruhi oleh kondisi lingkungan pembelajaran yang terdiri dari variabel instruksional yang ditentukan oleh variabel yang terkait dengan siswa. Oleh sebab itu guru harus tahu bagaimana mengembangkan kemampuan berpikir kritis siswa dalam pembelajaran yang diampunya (Tiruneh, Gu, De Cock, \& Elen, 2018).

Adapun menurut Lancaster (2014) menjelaskan bahwa guru yang professional harus dapat menerapkan pembelajaran berdasarkan standar pendidikan dan tujuan pembelajaran, yang kemudian dihubungkan dengan penerapan berpikir kritis ke dalam seluruh disiplin ilmu. Lebih lanjut, berpikir kritis memiliki sepuluh fungsi yaitu: (1) mengarahkan tujuan, memunculkan isu-isu tertentu, (3) memperoleh kejelasan data sebagai alat bantu menjawab sebuah pertanyaan, (4) menentukan asumsi, (5) menyusun definisi di dalam membuat suatu keputusan, (6) memberikan implikasi dan konsekuensi, (7) membiasakan untuk berpikir dengan kualitas tingkat tinggi, , (8) dapat mengetahui point of view, (9) sebagai self guidande dan (10) sebagi bentuk dari interpretasi (Inch, Warnick, \& Enders, 2006). 
Lebih lanjut, menurut Seventika, Sukestiyarno, \& Mariani (2018) menjelaskan bahwa karakteristik kemampuan berpikir kritis yaitu mampu menganalisis, mensintesis, menyimpulkan dan menilai. Adapun penjelasan indikator berpikir kritis sebagai berikut: (1) Analisis memiliki tujuan untuk memahami konsep dan mengklarifikasikan masalah global menjadi bagian yang kecil-kecil; (2) sintesis, kemampuan untuk menggabungkan bagianbagian yang terpisah; (3) mengenali dan memecahkan masalah merupakan konsep yang aplikatif mengenai berbagai definisi; (4) solusi merupakan pemahaman berdasarkan aktivitas penalaran; dan (5) evaluasi untuk dapat menentukan hipotesis atau kesimpulan suatu permasalahan.

Adapun dalam hal ini untuk meningkatkan kemampuan berpikir siswa dapat dilakukan melalui program layanan bimbingan dan konseling dengan memanfaatkan teknologi yang ada saat ini atau lebih mengarah pada penggunaan alat-alat internet yang berbasis cyber. Selanjutnya, dalam hal ini program layanan bimbingan dan konseling berbasis cyber akan dimanfaatkan untuk mengembangkan potensi yang di miliki baik kognisi, afeksi dan perilaku dari siswa (Prayitno \& Amti, 2004). Adapun menurut Blocher (1987) program layanan bimbingan dan konseling merupakan intervensi yang sistematis, telah terencana, serta ditujukkan untuk memaksimalkan kebebasan dan efektivitas manusia dan membantu individu agar menjadi menjadi lebih sadar atas dirinya sendiri. Berdasarkan pendapat tersebut maka dapat disimpulkan, program layanan bimbingan dan konseling merupakan proses pemberian bantuan yang dilakukan oleh guru bimbingan konseling atau konselor sekolah baik secara online maupun offline secara terstruktur guna memperbaiki tingkah laku siswa agar menjadi pribadi yang lebih baik.

Adapun, jika ditinjau dari fungsinya saat ini, maka layanan bimbingan dan konseling dapat berfungsi sebagai pencegahan, penyembuhan, pengembangan dan pemeliharaan (ABKIN 2008). Selain itu, dalam pelayanan bimbingan dan konseling terdapat prinsip dasar yang dipandang sebagai landasan bagi pelayanan bimbingan dan konseling yaitu dapat bermanfaat bagi orang lain. Prinsip tersebut diperuntukkan bagi semua siswa ataupun konseli, sebagai proses indivudasi untuk dapat berperilaku positif dalam berbagai seting kehidupan. Lebih lanjut, Prasetya \& Gunawan (2018) mengungkapkan jika dalam pelayanannya bimbingan dan konseling mempunyai empat komponen pelayanan yakni: (1) pelayanan dasar bimbingan; (2) perencanaan individual; (3) pelayanan responsif; dan (4) dukungan sistem. Pelayanan-pelayanan tersebut dapat dilakukan secara online dengan menggunakan media 
berbantuan internet atau berbasis cyber. Lebih lanjut, secara garis besar penjelasan singkat tentang keempat model pelayanan tersebut dapat dijelaskan sebagai berikut:

Pelayanan Dasar. Pelayanan ini dikatakan sebagai proses bantuan pada seluruh siswa atau konseli secar sistematis melalui pengalaman terstruktur kelompok maupun klasikal untuk mengembangkan perilaku jangka panjang yang sesuai dengan tugas-tugas dan tahap perkembangan siswa. Selanjutnya, pelayanan ini memiliki tujuan untuk membantu konseli, agar memiliki mental yang sehat dan memperoleh keterampilan dasar sesuai dengan tugastugas perkembangannya. Untuk mencapai tujuan tersebut maka, fokus perilaku yang harus dikembangkan menyangkut aspek-aspek sosial, pribadi, karir, dan belajar.

Pelayanan Responsif. Pelayanan yang kedua ini yakni bantuan kepada konseli yang menghadapi kebutuhan dan masalah yang memerlukan pertolongan dengan cepat atau segera, sebab apabila tidak segera dibantu bisa menimbulkan gangguan dalam proses pencapaian tugas-tugas perkembangannya. Pelayanan ini bertujuan untuk membantu konseli agar dapat memenuhi kebutuhannya dan memecahkan masalah yang dialaminya atau membantu konseli yang mengalami hambatan, kegagalan dalam mencapai tugas-tugas perkembangannya. Untuk mencapai tujuan yang diharapkan maka pelayanan responsif ini harus berfokus pada masalah atau kebutuhan konseli.

Perencanaan Individual, selanjutnya pelayanan individual diartikan sebagai bantuan oleh konselor sekolah atau guru bimbingan dan konseling pada siswa atau konseli, agar dapat meinterpretasikan dan melakukan aktivitas yang kaitannya dengan perencanaan masa depan dengan berdasarkan pemahaman diri akan kelebihan dan kekurangan, juga paham akan peluang yang tersedia di lingkungan sekitarnya. Secara mendalam kegiatan orientasi, konseling individual, kolaborasi, informasi, rujukan, dan yang terakhir advokasi sangat diperlukan sebagai bentuk implementasi pelayanan. Perencanaan individual bertujuan untuk membantu konseli agar (1) dapat melakukan kegiatan berdasarkan pemahaman, tujuan, dan rencana yang telah dirumuskan; (2) mampu merumuskan tujuan dan pengelolaan terhadap diri sendiri yang menyangkut aspek pribadi, sosial, belajar dan karier; (3) memiliki pemahaman tentang diri dan lingkungannya.

Dukungan Sistem. Dalam halini dukungan sistem, merupakan bentuk kolaborasi dari steakholder yang berkaitan untuk mendukung ketiga komponen-komponen di atas. Dukungan sistem merupakan sekumpulan kegiatan dan pelayanan tata kerja, manajemen, infrastruktur (teknologi informasi dan komunikasi), serta pengembangan kemampuan profesional dari 
konselor secara berkesinambungan, secara tidak langsung memberikan bantuan kepada konseli demi kelancaran perkembangan konseli.

\section{SIMPULAN}

Dalam hal ini, tugas utama dari penerapan layanan bimbingan dan konseling adalah dapat membantu konseli menjadi individu mandiri. Adapun bentuk sumber daya yang harus diperhatikan untuk menciptakan program bimbingan dan konseling yang baik yaitu: (1) sumber daya personil, dalam hal ini yang harus dilakukan adalah menyesuaikan rasio konselor dan siswa, mengembangkan jobdis dari konselor sekolah, menetapkan peran dan tanggungjawab, mengembangkan jobdis staff anggota yang berkegiatan dalam program bimbingan dan konseling, serta memperjelas hubungan antara organisasi pada program bimbingan dan konseling; (2) sumber daya keuangan, dalam hal ini yang harus dilakukan adalah menetapkan anggaran untuk program bimbingan dan konseling, menjajaki penggunaan sumber lainnya, mengembangkan program bimbingan dan konseling sesuai dengan sumber daya yang dibutuhkan, memberikan fasilitas standar bimbingan dan membuat rekomendasi untuk pengaplikasiannya; dan (3) sumber daya politik, dalam hal ini yang harus dilakukan adalah memperbaharui kebijakan dan prosedur, melahirkan dukungan dari staff, bekerja dengan staf, dan bekerja dengan orang tua siswa yang bersangkutan.

Adapun saran bagi konselor sekolah adalah dapat menerapakan layanan bimbingan dan konseling baik secara individu maupun kelompok dengan memanfaatkan media cyber yang terkoneksi internet atau secara online sebagai solusi dari permasalahan yang terjadi akibat pandemik saat ini. Selain itu konselor juga dapat mengembangkan media yang dapat digunakan untuk proses $e$-counseling yang sesuai dengan kebutuhan di lapangan.

\section{DAFTAR RUJUKAN}

ABKIN. (2008). Penataan pendidikan profesional konselor dan layanan bimbingan dan konseling dalam jalur pendidikan formal. Jakarta: Depdiknas.

Bhatt, R.M. (2010). Growth of computing technology for education in India. Journal HNB Garhwal University, India, 7, 92-102.

Blocher, D.H. (1974). Development Counseling. New York: Macmillan Publishing Company.

Cabaniss, K. 2003. Computer-related technology use by counselors in the millennium journal of technology in counseling. (http://jtc.colstate.edu).

Chotimah, S., Ramdhani, F. A., Bernard, M., \& Akbar, P. (2019). Pengaruh Pendekatan Model-Eliciting Activities Terhadap Kemampuan Berpikir Kritis Matematik Siswa Smp Negeri Di Kota Cimahi. Journal on Education, 1(2), 68-77.

Dahlia, Ibrohim, \& Mahanal, S. (2018). Peningkatan keterampilan berpikir kritis siswa SMP menggunakan perangkat pembelajaran berbasis inkuiri terbimbing dengan sumber 
belajar hutan wisata Baning. Jurnal Pendidikan: Teori, Penelitian, dan Pengembanga, 3 188-194.

Gibson, R. L., Santoso, Y., \& Mitchell, M. H. (2010). Bimbingan dan konseling. Pustaka Pelajar.

Hendriyani, T. (2019). Optimalisasi peran Guru Bimbingan dan Konseling Dalam Mereduksi Nomphobia

Inch, E.S., Warnick, E., \& Endres, D. 2006. Critical thinking and communication: The use of reason argument (Fifth ed). Boston: Allyn and Bacon.

Lancaster, J. (2014). School and classroom indicators of inclusive education. Measuring Inclusive Education International Perspectives on Inclusive Education, 3, 227-245.

Matlubah, H., Anekawati, A., \& Ngadi, N. (2016). Aplikasi Mobile Learning Berbasis Smartphone Android Sebagai Sumber Belajar Mahasiswa Program Studi Pendidikan Ipa Universitas Wiraraja Sumenep. LENSA (Lentera Sains): Jurnal Pendidikan IPA, 6(2).

Matthews, M., Doherty, G., Sharry, J \& Fitzpatrick, C. (2008). Mobile phone mood charting for adolescents. British Journal of Guidance \& Counselling, 36, 113-129.

Nafiah, Y. N., \& Suyanto, W. (2014). Penerapan model problem-based learning untuk meningkatkan keterampilan berpikir kritis dan hasil belajar siswa. Jurnal Pendidikan Vokasi, 4(1).

Prasetyo, R.Y \& Djuniadi. (2015). Implementasi e-konseling pada social learning network. Journal Edu Komputika, 2, 9-18.

Prasetya, A.F., \& Gunawan, I M.S. (2018). Mengelola emosi. Yogjakarta: K-Media.

Prayitno \& Amti, E. (2004). Dasar-Dasar Bimbingan dan Konseling. Jakarta: Rineka Cipta.

Tiruneh, D.T., Gu, X., De Cock, M., \& Elen, J. 2018. Systematic design of domain-specific instruction on near and far transfer of critical thinking skills. International Journal of Educational Research, 1, 1-11.

Triyono, T., \& Febriani, R. D. (2018). Pentingnya Pemanfaatan Teknologi Informasi oleh Guru Bimbingan dan Konseling. JUANG: Jurnal Wahana Konseling, 1(2), 74-83. 